\title{
ANTHROPOLOGICAL PERSPECTIVES ON ROMANIAN SOCIALISM. A CASE STUDY
}

\author{
Alina BRANDA \\ Babeș-Bolyai University, Faculty of European Studies, Cluj-Napoca, ROMANIA \\ alinabranda@gmail.com \\ DOI: http://doi.org/10.23740/TID120201
}

\section{ABSTRACT}

This paper aims to analyze mainly how and why Western anthropologists conducted fieldwork in Eastern Europe during the Cold War. What motivated their particular research interest in this part of Europe, how they understood these societies and socialist systems, what specific factors made possible and facilitated the fieldwork they had conducted in difficult times. These are the main research questions addressed in this paper. Specifically, I refer to their work carried out in the 1970s-1980s in Romania. In particular, I aim at analyzing the works of three reputable US specialists in the field, who manifested a research interest, and conducted fieldwork especially (but not exclusively) in different rural settlements of this country. The paper attempts to identify the ways in which the Romanian socialism is understood in its peculiarities by these notable anthropologists, analyzing their studies as results of intensive fieldwork.

Their works, published initially in English, in the USA, were translated into Romanian in the post 1989 decades, being received with high interest by "local specialists," as well as by the broader public. They are present in representative anthologies on socialism and postsocialism, as valuable contribution to the understanding of these periods. Despite all these, comprehensive analysis of their contributions is still lacking, as well as the comparative frames meant to facilitate the identification of both specificities and recurrences in their works, in the ways they viewed the impact of socialisms on various, studied communities. It is a necessary and useful task to revisit their works (as well as the works of other anthropologists who conducted fieldwork in Romania and broader, in Eastern Europe) to understand in depth their views, their meanings and relevance in that particular context and afterwards, as well as their contribution to the Anthropology of Socialism and Postsocialism. Through this, other fields and topics are opening to the analysis, such as the contribution and particular roles of the Anthropology of Socialism and Postsocialism in structuring the Anthropology of Europe, as it is configured nowadays.

Keywords: Eastern Europe, Cold War, fieldwork, Social/Cultural Anthropology

Cite this article as: Branda, A. (2020). Anthropological Perspectives on Romanian Socialism. A Case Study. Territorial Identity and Development, 5(1), 5-20. DOI: http://doi.org/10.23740/TID120201

\section{INTRODUCTION}

The present study has the following aims: the first one is to discuss how and why (westem) anthropologists manifested a special research interest in East European topics during the Cold war, how they managed to conduct fieldwork and to live in different communities of this part of Europe in difficult times. As I have mentioned in the abstract, I chose Romania as case study, and mainly the works of three notorious, US trained anthropologists, with a peculiar interest in this country, and who tackled (although not exclusively) topics related to rurality.

Secondly, I attempt to identify and underline the specificities of their anthropological perspectives, both when conducting fieldwork, and when constructing broader understandings of how, in particular, the socialist system functioned as such in Romania. Derived from this, we 
have at a glance the "social" /"cultural" images focused on communities, and at least a bit on the atmosphere of those periods, reconstructed both through the lenses of anthropologists and their interlocutors ( $I$ use, for instance, in one of the subchapters of this study, the anthropologists' subjective experiences when facing the Romanian realities, as they are presented in various texts as result of self-reflection).

The third attempt is to put this specific analysis in a broader theoretical frame, placing the anthropologists' work in the context of the anthropology of socialism and postsocialism, occasionally emphasizing their dynamics within the anthropology of Europe.

\section{THEORETICAL AND METHODOLOGICAL BACKGROUND}

Although my intention is to "reconstruct" the atmosphere of the 1970s-1980s in Romania, through anthropological texts (considered as main documentation sources) produced in that period, considering both the anthropologists' voices and perspectives, as well as the interlocutors' ones in their dynamics, I make (occasionally) references to the nowadays contexts, updating the discussion. To put it in temporal frames, this analysis attempts to combine diachronic and synchronic perspectives in order to have an accurate view on the topic and on how it has influenced the anthropological research on Eastern Europe afterwards.

Methodologically, the study is constructed on the basis of discourse analysis, and, as stated above, I have used as primary sources, studies produced as result of fieldwork conducted in 1970-1980s Romania, as well as the anthropologists' self-reflexive texts regarding their experiences when encountering the social life and atmosphere in this country.

My whole approach is based on the processes of reading, rereading and interpreting which are, in this case, double folded processes. Considering Wolfgang Iser's perspective on the act of reading as implying "becoming conscious", enabling ourselves to: "discover an inner world of which we had hitherto not been conscious" (Iser, 1978, p. 58) and also Ricoeur's views (1976) on the meanings of texts interpretation as processes facilitating the readers' multi-layered selfknowledge, I aim at analyzing how and why it is necessary to read or re-read anthropological studies on the 1970s-1980s Romania.

Through the process of reading these texts, the readers (both specialized and non-specialized) have, first of all, access to the anthropologists' perspectives focused on social and cultural realities. Simultaneously, they dive into the social/cultural "realities" of an already consumed period of time, some of them with certain personal/subjective experiences regarding it, some of them not having even a clue on it but having access to it through these texts, through the anthropologists' lenses. Therefore, certain interrogations regarding the compatibility or noncompatibility of the two perspectives (one of the author-anthropologist in this case, the other one of the reader) are triggered by this process. Implicitly, I tackle these topics, and I believe this attempt is not meaningless.

The issues of the necessity, relevance and meanings of "writing culture" (Clifford \& Marcus, 1986), reading and "rereading anthropology" (Marcus, 1992) are systematically approached by several theoreticians, notorious in interdisciplinary researches in humanities and specifically in cultural anthropology, mostly in the 1990s and afterwards. In particular, they analyse how and why "representations are social facts" (Paul Rabinow, 1986, pp. 234-262), as well as "Contemporary Problems of Ethnography in the Modern World System" (Marcus, 1992) or "Post-Modern Ethnography: From Document of the Occult" (Stephen A. Tyler, 1986, pp. 122- 
144), always stressing on the meanings of the reading/rereading, writing/rewriting anthropological texts, and of how ethnography is to be viewed in late modernity/postmodernity.

Other blocks of anthropological literature which had been consulted in the effort to find an adequate theoretical frame for this study are the ones discussing the role, meanings, and goals of anthropology of socialism and postsocialism in the framework of the Anthropology of Europe. In particular, the studies attempting to put together and to configure comparative frames in anthropology of socialism and postsocialism had been of tremendous help; through them (Hann, 1992, 2002; Buchowski, 2012), the research topics of high interest for western anthropologists had been easily identified, as well as the differences and recurrences of the social and cultural mechanisms profiled in various countries of Eastern Europe, as reflected in the anthropologists' perspectives. For instance, it is made clear how and why they chose to analyze distinct systems of property relations, from collectivized agricultural land in most of the countries to privately owned farms in Yugoslavia and Poland, and how and why private entrepreneurship was encouraged in these countries, as well as in Hungary in late socialism (Buchowski, 2012).

Then, when specifically referring to postsocialism, these studies are pointing out especially the divergences between the former socialist countries and how they have been deepened over the last decade, stressing on the fact that they are especially visible, when comparing Central European to Central Asian or Caucasian variants of postsocialism. How and why differencesare obvious when considering sociopolitical transformations in the post-1990 period, from smooth to conflictual ones is another systematically analyzed topic. Meanwhile, when speaking about homogeneous responses to the new, post-1990 contexts, the fact that these countries/societies combine the modern capitalist regime to past forms of political, economic structuring, as well as the current membership of certain postsocialist countries to EU are a few recurrent features (Buchowski, 2012).

The same blocks of literature stress on the fact that socialism and postsocialism are to be approached in their continuity, insisting that the term postsocialism evokes controversy, as "the notion is confined in practice to the pre-1989 Soviet Bloc countries, characterized by really existing socialism" (Buchowski, 2012, p. 69, using Bahro's term); this implies that socialism related practices are "deeply imbedded in these societies and have not been replaced by new ones over night" (Humphrey, apud Buchowski, 2012, p. 70). Meanwhile, the fact that postsocialism is to be analyzed relating local processes (responses, places) to global ones, therefore considering it in relation with post-colonialism and neo-imperialism (Chari\& Verdery, 2009), in the macro post-Cold War context, is also to be reflected upon.

This is also a topic to be related to the literature on the contribution of Anthropology of socialism and postsocialism to the articulation of the complex domain of the Anthropology of Europe, which deserves a special attention as well.

\section{WESTERN ANTHROPOLOGISTS ON EAST EUROPEAN FIELDS. A DIACHRONIC APPROACH}

Starting with the $20^{\text {th }}$ century, the above-mentioned researchers conducted comprehensive fieldwork in the 1970s in Romania, continuing to have particular research interests here even after 1989. Having pinpointed the spatial-temporal frames of reference, we introduce the main questions we debate upon and to which we intend to-at least partially-provide answers to in this study: what image of Romanian socialism is being upheld in the scientific bodies of work of 
these specialists? Having emerged from outside the system, through direct contact with the very communities they were studying, Western anthropologists who showed a keen interest in Eastern European lands had had access to the "native's point of view" as much as that was possible throughout the Cold War.

What added knowledge does their particular interpretation bring into focus? What is the underlying rationale behind the decision of turning their research efforts into a much more complex process of understanding what has been and "what comes next"? (cf. Verdery, 1996). To what extent do these studies hold an intrinsic documentary value as they narrate people's daily existence in different locations in Romania of that period?

These are questions we intend to focus on in this study, selectively analyzing certain perspectives formulated by anthropologists in the USA regarding the fieldwork related experiences they had in Romania. Consequently, we pay special attention to their considerations on aspects concerning rurality, formulated in various studies that describe property relations, the impact of collectivization of agriculture on peasant/rural communities, the existing rituals as well as the relationship between ideology, rituals and religion. The authors I refer to most often are Katherine Verdery, Gail Kligman, and David Kideckel.

The Manichean visions of the post-1989 period extended (this time in a different sense) the same dichotomous logic of the Cold War, whereas the anthropological studies we refer to contribute to the dismantling of this reductionist perspective, both before and after 1989.

It is common knowledge that they had been published in that period in the authors' corresponding countries of origin, and consequently they were initially catering to a primarily Western audience. Only after 1989, through their translation, they became known to the interested "audiences" in Romania. Due to censorship related reasons, their publication during the full-blown communist regime would have been impossible.

From a theoretical standpoint, a discussion in connection to these approaches would inadvertently imply their categorization under the anthropology of socialism (cf. Hann, 1992) The very anthropologists activating in Eastern Europe have systematically shaped up demonstrations putting forward arguments in favor of the use of this phrase that encompasses the studies that were published as a result of the fieldwork that had been done especially after 1970 in various places from the Eastern Bloc. This systematic effort to collect the outcomes of research carried out in different communities in Romania, Bulgaria, Hungary, and Poland, to assign them to a common denominator, dates back to the $1990 \mathrm{~s}$.

These material documentation and systematization efforts reveal the diverse thematic red threads (a part of the studies focusing on the rural economies, whereas others mainly shedding light on the area of existing transformations in people's social status or on rituals), depicting differences in the organizational systems of the socialist countries. At the same time, they bear relevance with reference to the specific ways people relate to the economic-political Eastern Bloc realities of the period; additionally, there is emphasis on the mechanisms of systemic functioning, as well as on the unifying nature of these experiences.

An interesting approach has been adopted in order to provide a compare and contrast framework of the Eastern European socialist systems and the former Soviet Republics in Central Asia or in the African Republics. These endeavors illustrate the existing diversity of the approaches used for the socialist period to be articulated, produced and lived in different parts of the world; the outcome is therefore its nuanced comprehensionfrom the point of view of the common people and their respective communities. On the other hand, the anthropology of 
socialism conceptually emerges as a sub categorized thematic and temporal area through its reference to the anthropology of postsocialism (cf. Hann, 1992), being defined simultaneously with ongoing transformations in the same societies/countries in the period following 1989/1990. These are the theoretical, methodological, and thematic frameworks that have to be discussed in a detailed and multifaceted way so as to undergo as comprehensive an analysis as possible of anthropologists' activity in Romania, both during the Cold War period and afterwards.

In order to adopt an appropriate structure of the present study, I organize its content in a series of content points/brief sub-chapters meant to depict the important significance of the body of research that has been done on Romania, at the same time highlighting its own limitations beyond obvious achievements.

The above-mentioned sub-chapters focus on:

1. The period during which the anthropological fieldwork has taken place, the underlying conditions and the corresponding risks and limitations;

2. The outcome of the Western anthropologists' approaches, as well as the emerged Eastem European image through their lenses used in order to reach a predominantly Western audience during and after the Cold War. These anthropologists are fine observers of the Eastern-European research field;

3. A few aspects connected to the rural issues depicted and analyzed by the above-mentioned researchers.

\section{Anthropological field. Conditions, risks, limitations}

In a reflective way, Western anthropologists who conducted fieldwork in Eastern Europe and in Romania in particular, during the Cold War period, analyzed the existing rationale behind these chosen locations, as well as their conditions of possibility, especially in the 1970s. Romania of that period drew the attention of the European anthropology and ethnology experts in various Western countries: Jean Cuisenier, Claude Karnoouh (France), Marianne Mesnil (Belgium), Paul Nixon, Ann Buckley (Great Britain), to name only a few (they carried out fieldwork in various locations in Romania, starting with the 1970s; nevertheless, their specific interest in particular topics and places manifested itself after 1989/1990 as well).

In the following part of this study, I focus on detailing the activity that has been done by several USA anthropologists who had had a particular research interest in Romania of the period, consistently being engaged in researching specific topics on the very same field, after 1989. I do not wish to justify further on my choice of these particular authors at this point; nevertheless, I underline the fact that this subject is to be tackled through different (complementary even) standpoints connected to socialism, which have been documented and articulated by other specialists of the field in Western Europe. To start with, why was there an interest in various aspects connected to socialism? Why has Eastern Europe become a research interest for anthropologists during the Cold War period, bearing in mind the well-known fact that in earlier stages of cultural anthropology as a field of study, there had been other parts of the world that had been labeled as more attractive, since they were associated with an increased research potential by experts? In the colonial period, social-cultural anthropology mainly focused on studying societies that tailored themselves onto the "primitive", "exotic" and "backward" model. 
In a study entitled Anthropology Comes Part Way Home. Community Studies in Europe, drawing on John Davis's perspective, John Cole stated that this particular cliché had dominated the anthropological world for a long period of time:

"Anthropology is only anthropology if it is done very much abroad, in unpleasant conditions, in societies very different from the ethnographer's habitat, very different indeed from the sort of place where he might go on holiday." (Cole, 1977, p. 353)

Conversely, the European societies, including-to a certain extent-Eastern and Southeastem ones, found themselves outside this basic scheme and therefore did not constitute a target for many field experts.

There were also other additional reasons behind this low interest: Eastern and South Eastern Europe were not colony territories. Most of the peoples that inhabited this territory had a specific history that was different from both the Western Europe powers' and that of the colonies. They had been incorporated in multinational empires-Habsburg, Ottoman, Tsaristbeing involved in the process of national emancipation in modern times, pursuing the development of nation states. Social-cultural anthropology was mainly a Western product that had to primarily focus on the study of colonial territories of the Eastern-Western power states.

During the Cold War, the regimes in Eastern Europe, located in the area of Soviet influence, had become of great interest to Western anthropologists in terms of social, economic and political frameworks-which were different from the Western ones-stimulating specific living circumstances within the existing communities. To put it more simply, these regimes have put specific types of pressures on the part of the population at macro, community, and individual level in terms of cultural manifestations and idiosyncrasies. Due to all these, particular life forms configured in Eastern Europe during the Cold War had started to represent the cultural difference that was obsessively sought by anthropologists; it is common knowledge that cultural/social anthropology has emerged as a field study of cultural otherness, this legitimacy being so deeply internalized by the field that even after the abandonment of classical nonEuropean anthropology lands, it still remained ingrained in its code.

Conversely, an Eastern Europe anthropology was possible due to field mutations and reinterpretations that occurred simultaneously with the disappearance of colonial Empires and the overall association of cultural anthropology with the exclusive study of primitive, exotic and devoid of written history peoples; there is an obvious flexibility in the field choices and subjects under discussion, a deep internal crisis within the field itself. ${ }^{1}$ These transformations have enabled the research done on Eastern Europe throughout the Cold War.

Specifically, the USA experts' anthropological bodies of research were made possible in an apparently tension loosening period in the East-West relations in the 1970s. As pointed out by Katherine Verdery (1996), organizations such as IREX-International Research and Exchanges (in 1968) - and The National Council for Soviet and East European Research (in 1978) had been directly involved in facilitating, promoting, and financing the ongoing research endeavors in Eastern Europe (Verdery, 1996, p. 5).

Due to an increased interest in Western technologies, the socialist states had allowed the Western specialists' access to the area as a token of a certain trade-off, a certain mutuality being retrospectively analyzed by anthropologists having an Eastern European research agenda. Additionally, the interest manifested by American politicians towards the understanding of the

${ }^{1}$ As we have already stated, these ideas are minutely presented by John Cole (1977), in Anthropology Comes Part-Way Home: Community Studies in Europe. The Annual Review of Anthropology, 6, 349-378. 
functioning mechanisms of Eastern-European socialism(s) is put under analysis in a comprehensive and systematic manner. Anthropologists were therefore contributing to this knowledge gain.

We can safely claim that there was a favorable context for this research to occur in the 1970s. Below, Katherine Verdery focuses on the aforementioned context:

"I began preparing to work in Eastern Europe in 1971. In the most general sense, research there at that time was possible only because a Cold War was in progress and had awakened interest in the region, and because that war had abated somewhat into détente." (Verdery, 1996, p. 5)

Moreover, the author further explains her option for Romania, mentioning the fact that field research was permitted, if not encouraged even, offering details connected to the political context of the period, whereas insisting on the possibility to conduct research and on research conditions in this country, as well as on the apparent openness of Ceaușescu's regime combined with USA Government's manifested interest to research the area. These observations are meant to nuance the frameworks of that decade of the Cold War, reconstructing the atmosphere and emphasizing the issue of reciprocity of the research interests related to the two countries in different antagonistic blocks.

Recreating the period atmosphere, characterized by overbearing conflicts, major unrest and scarring traumas, David Kideckel states that:

"At the beginning of the 70s, the Vietnam was unfolding, the Watergate scandal was getting extensive daily media coverage whereas socialism was an expanding system whose underlying rationale was the equality of human relations and national development. To a certain extent, Romania and Ceaușescu were guiding lighthouses within this unfolding international movement. Nicolae Ceaușescu's denouncement of Czechoslovakia's invasion, the 1968 Warsaw Pact violation as well as the apparent liberalism of his politics at the end of the 60 s were conducive to a positive morale supporting our desire to rationally explain Romania's misfortunate events and ill-advised institutions." (Kideckel, 2006, p. 19)

Despite the apparent regime openness that the specialists had become aware of, the demonizing discourses inherent to the dichotomous logic of the Cold War were bound to leave an imprint on the experts' behavior during landscaping: anxiety, the dread caused by the agents took their toll as David Kideckel humorously remarks:

"I will never forget the absurdity of the days that were spent microfilming five-year maps and forecasts that had the top secret stamp on and which had been provided to me by the Planning Office of Brașov County. Each time the office door was flung open, I would freeze with the certainty of being arrested. When a high rank Communist Party official came in and saw what I was doing, I started stammering and clumsily operated the equipment in my hands. He smiled and pressed his hand onto the page the planning book was open at so that I could take a better picture of it. Certainly, the Cold War statements that I had been raised around did call for a re-evaluation." (Kideckel, 2006, p. 19)

Within this time reference, the interest in Romania is even institutionalized as many highly acclaimed anthropologists were being motivated to engage in specific research here due to the obvious willingness of this country to welcome researchers whose field research was possible despite certain limitations being enforced. Thus, in 1977, The Romanian Research Group was created boasting such renowned specialists as Sam Beck, John Cole, David Kideckel, Marilyn McArthur, Stevan Randall, and Steve Sampson.

Gail Kligman's Honoris Causa reception address (Kligman, 2017) is undoubtedly an extraordinary source of information in relation to the field conditions of the period as well as its difficulties 
and restrictions, people's daily existence and some crucial problems they were confronted with.

It is an extremely profound, self-reflective discourse, detailing the approach used on the field leading to the publication of some of her most relevant studies which have gained recognition and citation weight from experts in various fields, not only in anthropology. The anthropological effort highlights and empowers the native's voice as the insider who is an inherent part of a system; anthropological texts by definition may be covered as authentic, genuine, unaltered and unmistified documents about the individuals' life from the time frame that is under observation. The readers are informed on Romanian communism through the very people that experienced it, facing its challenges. We will hereby revisit Gail Kligman's main content points in the abovementioned text.

In her discourse, the motivation behind choosing Romania for anthropological research is systematically touched upon. Having been initially attracted by former Yugoslavia, the author had not been granted approval from Yugoslavian authorities and consequently turned her attention to Romania. Together with the country choice itself, these themes of opting for communities and locations in Romania are consistently revisited by anthropologists who had research focus here. This reality is completely natural in any contemplative endeavor that involves qualitative methodology:

"In the 1970s, Romania in comparison with other socialist states was relatively open to the presence of foreign professors and researchers. As you know, Romania did not participate in the invasion of Czechoslovakia, after which the West looked favorably upon Ceaușescu." (Kligman, 2017, p. 20).

In the same piece of discourse, the first interpretations of people's daily lives under communism occur, ranging from the organization of vegetable markets to a "milițian's" suspicions, as he was in charge with the surveillance of such a market in Bucharest. Rooted in such detailed accounts, the period atmosphere is being reconstructed by using a necessary memory appeal that stems from these researchers-fine observers of that period. This type of evidence is interesting, and worth being documented through a more complex effort pool, so as to obtain a comprehensive overview of Romanian communism adding value to a better, more nuanced understanding of the period under discussion.

The population surveillance mechanisms are also consistently recorded. The authorities' strategies to "keep careful track of" the foreign researchers despite offering a seemingly free field access are documented in minute detail.

In a reflective way, Gail Kligman records the time frame of her studies, mentioning her recurrent research interests. Thus, the dynamics of ritualistic practices, the ritual/religion-ideology relation and the ways in which communities are affected by the policies of the totalitarian state also come into focus. Consequently, the coping mechanisms used by the respective communities to lead their lives without diverting from respected cultural norms become various subsistence strategies in themselves. These themes are-in turn-specifically discussed in a series of studies that primarily target the Western audience.

As the author herself states in the aforementioned Doctor Honoris Causa acceptance speech, apart from offering an analysis of "dramatic peasant culture changes in the industrialized socialist state" (Kligman, 2017, p. 22), she had also had a keen interest in the way the totalitarian state intended to control and censor the authentic ritualistic manifestations of the Căluș (Kligman, 1981), by resorting to the organization of the "Romanian Căluș" annual festival in the Olt region. 
The postdoctoral content is interesting both as a sign of consistency in studying topics rooted in anthropological practice through direct contact with her interlocutors and as documents depicting life under Romanian communism. Against the backdrop of the century atmosphere, by using humor and a certain degree of attachment, Kligman recalls how one incident related to a witch's death has contributed to a switch of focus; the witch had been regularly visited by nomenclature representatives so as to help them to envisage the future, stirring the researcher's interest to interview her as part of research done on this subject. The fieldwork and the direct contact with people have been the deciding factors in choosing a range of specific topics that she later focused on in Romania. Systematically, the reader is informed on how the researcher had been accepted and given accommodation in leud village, explaining the way in which she was made welcome with both suspicion and curiosity, having been invited into the guestroom, aunt Juji's good room, in accordance with the local traditions. The researcher makes many references to Romania's intellectual elites, apart from the rich content on life in the countryside painted by activities unfolding in leud within the analyzed time frame. There are thorough accounts of how they helped her in the organization of field research, constantly supporting her actions as they considered it important and relevant; also, stories about the way in which she was constantly being monitored by state agents: everymovement, every field development was systematically analyzed. As a consequence of her thirteen months stay in leud, where, in her own words, she has undergone ethnographic field research on such subjects "as weddings, funerals and weddings of the dead" (Kligman, 2017, p. 23), she published her work entitled "The Wedding of the Dead" (Kligman, 1988). ${ }^{2}$

According to her own description, the study is "an analysis of the cultural semantics of life and death, of ways in which individuals and communities give meaning to these rites of passage experiences" (Kligman, 2017, p. 23), within the context of a regime that controls and censors such practices; the specific interest in studying the ideology/ritualistic practices relation is obsessively mentioned, including in the Căluș study. The most important difference between the approach used to undergo fieldwork for better understanding of the Căluș and The wedding of the dead respectively is also marked: in the former, the field was itinerant, covering more communities/locations where the ritual was being performed; the latter included prolonged and intense fieldwork undergone by the author alone, resulting in a realistic overview of the countryside micro-cosmos in Romania, including its social relations, specific responsibilities of the community members, its period difficulties together with the positive aspects-all presented in a nuanced manner whose main strength is its unbiased quality. All these aspects are articulated within the framework of the cultural anthropology domain, without generalization intent, starting from the author's local life experience in the leud village, within the historical Maramureș County.

In similar fashion, The Politics of Duplicity (Kligman, 1998) ${ }^{3}$ starts from an analysis of the disastrous consequences of pro-natal demographic policies, especially of the 770/1966 Decree (Abortion Banning Decree) on women in Romania and it concludes by proposing an analysis of power exercising mechanisms by the totalitarian state. These mechanisms generate duplicity and social schizophrenia, essentially different coping individual manifestations in the private and public sphere, making use of perverted policies and practices that culminated with the totalitarian state intrusion into the private family lives. The book offers a narrative immersion into life in communism through life stories and anecdotal evidence. The study is founded on

\footnotetext{
2 Translated into Romanian in 2005.

3 Translated into Romanian in 2000.
} 
provided narratives from her interview interlocutors who had been mainly women that had experienced abortions performed in illegal, horrific, and life-threatening circumstances.

Another study of the period in question is suggested by the author in a rather diachronic fashion under the volume titled Peasants Under Siege: The Collectivization of Romanian Agriculture, 19491962 (Kligman \& Verdery, 2011). This publication is the result of Katherine Verdery's initiation of and participation in a multidisciplinary project that has included up to fifteen native specialists; it offers a comprehensive analysis on the collectivization period primarily perceived through its impact on the communities and as "a historical ethnography of the state". Pursuing the same loyalty to her previously manifested research agenda, Gail Kligman and her collaborators comprehensively analyze the same mechanisms employed by the totalitarian state in order to immerse into people's lives, their daily routines, while putting a mark on them through the specific decision loaded forms. The explanation behind choosing agriculture collectivization as an analyzed phenomenon is offered by the author in the above-mentioned text:

"In predominantly agrarian countries such as Romania, the collectivization of agriculture was the first mass campaign through which the new communist regime inaugurated its radical program of social, political, economic and cultural transformation. Through collectivization, the nascent Party-state created its mechanisms of rule and authority, but not without push back from the populace. Collectivization may have been directed from the center, following directives from Moscow, but it was implemented locally." (Kligman, 2017,p. 26)

The debate surrounding the choice of subject is doubled by the questioning of limitations of the used method-namely the archive study-that has proven to be problematic in the sense of restricting access to various qualitative sources and methods employed by researchers, especially in oral history. These limitations are connected to the interviewees' memory and their indirect influence by the political context of the period the interviews took place in (Kligman, 2017, p. 27).

A whole atmosphere is recreated once more as the author ponders on her archive research. The population surveillance mechanisms, the punishments against the citizens contravening the system are also brought into discussion in the same text (Kligman, 2017, pp. 26-27). For instance, the life of the anticommunist resistance group members from The Iza Valley is carefully observed and documented: one Securitate victim was reported missing in the same area, etc. These are specific instances that, nevertheless, report back on the general outlook of that situation in Romania.

One relevant question stands out from the Western anthropologists' texts: to what extent are people's daily lives and routines depicted in their studies? How far have they managed to illustrate through their research the various social problems of the period? These diverse specific situations range from the way in which they have managed to reveal social problems connected to the period to the way in which they create new life coping strategies in the context of agriculture collectivization to the transformations happening in the property system or the way in whichdespite the ideological intrusion-community cultural rules and ritualistic acts are upheld.

The present study sheds light and brings into close focus the specialists who have systematically and enthusiastically documented communities' lifestyles, paying attention to the strategies used in order for them to adapt to the changes which were imposed by the regime. Emphasis was also placed on people's local interpretation of centralized decisions forced by the totalitarian state or on the way in which individuals create identity survival coping strategies in their attempt to respect their own set of cultural values.

The complex field research done by the Western anthropologists in Romania of that period has 
generated various subjects. By focusing on these subjects, they have also underlined the difficulties and limitations of their research in a time frame that included fierce population control, ideological censorship and visceral fears projected onto every foreigner, who was attempting to enter the system. In recent times, several anthropologists have asked CNSAS (the National Council for the Study of the Security Archive) for permission to access their own files, having been certain that they had been carefully monitored throughout their field research by Securitate agents infiltrated in diverse population categories (Verdery, 2018).

Indeed, their activity in Romania and in other countries of the Eastern Bloc has given rise to debates in connection to the manner used by population surveillance institutions (The Securitate in Romania) to keep track of researchers' ongoing activities. During the Cold War, the Securitate agents held the strong belief that Western specialists were being provided security training by their countries of origin, being involved in "espionage" dealings in its various manifestations. Truth be told, anthropological practices do include field notes and observations, the informant's name codification, the recording of data on informant's social background; hence, there was a general perception that was held with reference to anthropologists' work as Securitate agents compared this type of documentation and their own population surveillance activities (cf. the contention developed by Poenaru, 2017).

Holding the firm belief that anthropologists were engaging in spying related activities, it was not long before the observation measures were enforced either indirectly as a discreet "support/assistance" provided by colleagues activating in research Institutes in Romania or, in a more direct manner through the actions of Securitate agents. The open access granting to the Securitate files, combined with the CNSAS activation, as well as the enforcing of necessary conditions for Western anthropologists to access their ownfiles and to reflecton the way they had been monitored have generated heated discussionsand debates on the subject (Verdery, 2014).

In the next part of the study, I am going to talk about specifically addressed research issues, attempting to identify certain recurrent characteristics that can be consistently identified in the anthropological research on Eastern-European regimes, features that are easily noticeable in the approach Romanian socialism is analyzed in. In what follows next, we proceed to pin them down and discuss them one by one. Firstly, we have to highlight the fact that the comprehension of the systemic functioning mechanisms occurs at a later stage, following the analyses of particular topics singled out within a community that is extremely well delimited in terms of space: leud, Aurel Vlaicu and Hîrseni traditions, rituals, agriculture collectivization, etc.

The preference for using the term socialism associated with an implicit hesitation in using the term communism represents another recurrent feature made apparent in anthropological analyses focusing on one particular topic, as well as in the theoretical attempts or in the highly comparative studies:

"I prefer this term to the term communism that was not claimed for exemplification by any of the countries in the Soviet Bloc. All were governed by communist parties but they at the same time identified themselves as socialist republics, on their way to true communism." (Verdery, 2003, p. 10)

This fact is clearly illustrated by the studies published in the Cold War period, which had been known only by Western audience (due to existing totalitarian censorship) and, especially The Anthologies published in the 1990s (cf. Hann, 1992; Verdery, 1991). Without exception, these publications containing anthropological studies on different topics, attempting to collect them in the same framework, while emphasizing the differences and idiosyncrasies within the research fields, bring into discussion the term socialism in order to define the encompassed 
systems under focus. The reason behind the term choice is similar to the one provided by Katherine Verdery, which had been mentioned above.

Upon mentioning the repetitive features of these studies and the potential interpretative models, we have to acknowledge the fact that-without exception, from the point of view of its mechanisms-socialism is perceived, understood and conceptualized through its relation to postsocialism; its characteristics are obviously easier to grasp using the comparative grid. Even if I have approached this specific topic in the first part of my study, considering it relevant, I still underline a few aspects related to it, now detailing as it follows. As mentioned, these two concepts shape up two frameworks that support each other: postsocialism analyses involve an analysis of socialism, as socialist practices had been strongly internalized for a long time and it was virtually impossible for them to disappear overnight (see Buchowski, 2012).

Moreover, after conducting fieldwork in various settings marked by socialism, including Soviet republics located in the Asian zone or certain African states, we have to notice the fact that the comparative frameworks reveal the diversity of these "socialism(s)," their particularities (a consequence of backgrounds, contexts, different cultural acquisitions), simultaneously referencing the unity that connects them as operating mechanisms. The recurrent tendency at this level is to approach socialism(s) both in their unity and in their diversity: the common background has to be identified; still, it is equally important to emphasize the existing nuances of the socialist systems and to reconsider all forms of socialism, not just the Eastern-European ones.

The relationship between these anthropology specialists with the Western left ideology is an extremely complex one, as the desire to understand as correctly as possible the Marxist approaches is supported and enhanced through the contact with the Romanian terrain and the Eastern-European one respectively:

"In 1975, upon my return to the research field, I discovered neo-marxist writings connected to this topic and I was employed by a department where Marx's intellectual heritage was highly praised." (Verdery, 2003, p. 19)

Consequently, USA anthropologists often place emphasis on the difference between theory socialism that "promised workers dignity and freedom, equal pay for equal work to women and equal state rights to national minorities" (Verdery, 2003, p. 10) and applied socialism:

"[...] the application of socialist programs encountered unexpected obstacles; the attempts to rectify ended up corrupting the objectives, occasionally resorting to horrific abominable policies leading to the torture and death of hundreds of thousands of people." (Verdery, 2003, p. 10)

According to Verdery, this chain of events has caused the gradual "denouncement of left-wing convictions by many loyal marxists" (Verdery, 2003, p. 10).

These are but a few of the recurrent elements that are analyzed in the work of anthropologists that have had a vested research interest in Romania and Eastern Europe in general. They reveal a clearly established plethora of subjects, as well as a certain anthropological interpretation unity associated, at the same time, with the inherent field diversity and diverse socialism nuances that are found in these settings.

The outcomes of western anthropologists' approaches, who have rendered themselves keen observers of the East-European fields during the Cold War

The outcome of these research efforts made by American and Western Europe anthropologists are carefully analyzed and deconstructed especially post-1990, through a much-needed self- 
reflective exercise. What was their role in the Cold War period? To what extent have they contributed to the dismissal of the dichotomy and incriminatory discourses of the period? All these theses are questions that are provided with anthropologists' feedback also in the 1989/1990 period.

Through their research efforts and the subsequent publication of their outcomes under the form of articles, studies, volumes, these specialists have successfully managed to diminish the effects of feeble annihilating and accusing Westernized discourses related to Eastern Europe. These discourses constituted the results of the logic of dichotomy, heavily promoted during the Cold War:

"I wanted to experience life as it was there, not to criticize their system or our system. When I started my field research, I had read neither Marx nor Lenin." (Verdery, 2003, p. 18)

On the other hand, David Kideckel (1993) further highlights the daily routine depiction approach through which ethnographic descriptions provided a more authentic image of the realities of what was unfolding in different parts of Eastern Europe for the Western readership.

Implicitly, anthropologists have managed to hold up the mirror to two very different socioeconomic systems, emerging to provide a critical analysis of socialism and liberal democracies alike, especially of the market economies-categories associated with the Western world. This idea of building a critical discourse on the Western socio-economic and political categories comes across as a constant concern for both types of anthropologists: the ones that had been engaged in field related research in Romania and the ones that had analyzed other locations in Eastern Europe.

\section{The rural issues as analyzed by the mentioned researchers}

The rural issues have often presented an important research interest that was analyzed by anthropologists who were interested in Eastern Europe in the Cold War period, alongside the imposed transformations by the local political regimes. A great deal of interest was given to the study of the coping strategies used within the countryside universe in order to deal with the collectivization period; from the ways in which rural communities had adapted themselves to the new property system, enforcing subsistence coping strategies, creating and recreating their own social identity.

In the next part of the present study, we mention several of the most significant titles/publications/studies/volumes whose major focus is the rural reality, trying to illustrate how the countryside life is being depicted by a few US anthropologists who had become interested in Romania of that period and consequently authored the studies in question: Katherine Verdery: Transylvanian Villagers. Three Centuries of Political, Economic, and Ethnic Change (1983), The Vanishing Hectare: Property and Value in Postsocialist Transylvania (2004), Chiaburii vechi și noi. Închiaburirea și deschiaburirea țăranilor din Aurel Vlaicu [Old and New Kulaks. Kulakisation and Dekulakisation of the Peasants in Aurel Vlaicu] (2005), Peasants under Siege: The Collectivization of Romanian Agriculture, 1949-1962 (with Kligman, 2011); Gail Kligman: Căluş. Symbolic Transformation in Romanian Ritual (1981), The Wedding of the Dead: Ritual, Poetics, and Popular Culture in Transylvania (1988); David Kideckel: The Solitude of Collectivism: Romanian Villagers to the Revolution and Beyond (1993).

Without setting out to perform a detailed analysis of the referenced volumes, we try to identify several recurrent themes documenting rural reality in these publications. They describe local cultures and communities, the strategies used by rural communities in order to react and adapt to "the new times". I also aim to highlight invariants of the socio-economic operating 
mechanisms, characteristic of the socialist state of the 1970s and 1980s.

Some of these studies analyze and develop the contexts of collectivization and decollectivization respectively, the way in which rural communities have adapted to these processes, further explaining how the new property type has generated new affinities, social networks, the quota problem:

"In 1948, the Party had requested that each family should provide a quota of their agricultural produce whose quantity increased proportionally with their property size. This obligation was enforced on the one hand to force villagers to enter agricultural cooperatives, and on the other hand to ensure that the postwar state had an appropriate amount of food supplies in order to fulfill its industrial ambitions." (Verdery, 2003, p. 211)

The resistance strategies employed by villagers in that particular period draw anthropologists' attention gaining research momentum:

"A solution to the problem was to either donate or sell the lands to one's relatives under the mutual agreement that the transfer/sale was to be fake." (Verdery, 2003, p. 212)

The identification of the actors involved within this hierarchical model are consistent preoccupations anthropologists focus on as they strive to understand the intricacies of the system, to reveal its operating mechanisms. At this particular level, I relate a significant part of my analyses to such topics as lack of communication and appropriation between central planners (the ones shaping up the planning), the factory directors and the workers respectively, as they were agents of a certain rupture, a particular social schizophrenia, a productivity blockage, real economic problems and crisis (cf. Cucu, 2019, for a recent approach).

An extensive body of research details the creation and operation of the Agricultural Cooperative Farms (ACF), the guiding principles they had been founded on, the ways in which the land was administered and worked on. Similarly, researchers also focus on the new property regime marking people's lives, the former owners' frustrations, the ongoing disputes, the youth situation in the new contexts:

"In Agricultural Cooperative Farms work was done on large parcels of land not in the maze of the small plots of the $30 \mathrm{~s}$. In order to create these huge areas of land, all signs of delimitation that would differentiate one plot of land from another had to be eliminated: trees and hedgerows were cut down, landmarks were removed;" (Verdery, 2003, p. 216)

"Agricultural Cooperative Farms (ACF) had been authorized to assign property rights to their members especially under two forms: agricultural land and the right to use the so-called personal allotments owned by ACP members. The village youth who wanted to build houses, the people who moved into village from other locations or the villagers that owned houses at the outskirts of the village and wanted to move closer to its center-could all apply to the ACF for a land to build on." (Verdery, 2003, p. 216)

The world of the village/countryside is depicted in this manner whereas the social-economic functioning mechanisms are also gradually unriddled. The way in which both the rural and the central authorities have manipulated to their own advantage an already existing situation in the villages is also debated upon:

"Being pressed to increase production, authorities were glad to observe that the peasants had hidden away land, a fact that allowed them to artificially pump up productivity by planting and harvesting fields that had originally been recorded as smaller than they really were."(Verdery, 2003, p. 212)

"[...] the difference could have been an award or a promotion for the mayor." (Verdery, 2003, p. 213) 
The issue of land elasticity, a central one within the postsocialist context, is analyzed at its causal, natural, historical and temporal levels; consequently, a valid understanding of property restoration is articulated on the basis of this analysis: the harsh realities of the property restitution processes, the fight for obtaining family agricultural plots, village born individuals and the newcomers-these aspects are also focused on in the post 1989/1990 context.

It becomes self-evident that the village, the rural world within the Romanian communism, as well as within other Soviet Bloc countries, is not only debated upon through these specific topics' standpoint. There is an array of topics that have caught the anthropologists' attention, observation, and interpretations, from subjects such as ethnicity, the newly formed social layers, or the economic issues. These aspects deserve careful analysis and discussion in particular contexts. Another significant body of anthropological literature has emerged on the topic of rituals, more specifically, on the existing connections between ritual/religion/ideology; one of the aforementioned sub-chapters of this study marks this subject by referencing Gail Kligman's Căluș (1981) and The Wedding of the Dead (1988).

\section{CONCLUSIONS}

It is necessary to analyze the dynamics supporting the interest shown to Romania at a more extended level that is Eastern Europe in the period after 1989-1990. As we have stated before, postsocialism was-in its thematic complexity-analyzed by a series of field experts, who were keen observers, possessing highly knowledgeable expertise as they had conducted extensive research in the area during the socialist period as well.

In these circumstances, the socialism/postsocialism comparative model is a compulsory one in order to understand both frames of reference. The fieldwork conditions have become much more accessible within a complex field that lends itself more readily to a generation of native anthropologists, who are equally interested to approach topics in the framework of what is called anthropology at home.

In a concluding remark, we can state the fact that-beyond their sensible analysis-the Eastem Europe/Romania related anthropological texts on socialism have enabled the critical examination of several thorny issues of the free market economies and liberal democracies, resulting in a critique of the Western cultural categorizations. This idea is supported in various forms by the majority of the anthropologists who have expressed interest in the region, being either directly or somewhat implicitly expressed through the allowance of circumstances that have facilitated the juxtaposition of two systems, of two worlds founded on different principles and guidelines. Additionally, these anthropological approaches have been conducive to the process of crystallization of methods of doing fieldwork in Eastern Europe (Cole, 1977) or at home, demonstrating that the ethnography processes no longer need to be realized exclusively outside Europe. Inadvertently, these processes facilitate the emergence of a field of European Anthropology that has been increasingly promoted and publicized since the 1980 s.

These analyses have additionally contributed to a reevaluation of the identity/otherness relationship in anthropology, advocating more and more for introspective approaches within this science, at the same time encouraging reflexivity and a profound re-assessment of the classic divide between the Eastern Europe and the West. This movement has highlighted the existing sensitivity in further discussing and analyzing the major crises of the modern world. 


\section{REFERENCES}

BUCHOWSKI, M. (2012). Anthropology in Post-socialist Europe. In U. Kockel, M.N. Craith, \& F. Jonas (eds.), A Companion to the Anthropology of Europe (pp. 68-88). New Jersey: Wiley-Blackwell.

CHARI, S. \& VERDERY, K. (2009). Thinking between the Posts: Postcolonialism, Postsocialism, and Ethnography after the Cold War. Comparative Studies in Society and History, 51(1), 6-34.

CLIFFORD, J. \& MARCUS, G.E. (eds.) (1986). Writing Culture. The Poetics and Politics of Ethnography. Berkeley and Los Angeles, California: University of California Press.

COLE, J. (1977). Anthropology Comes Part-Way Home: Community Studies in Europe. The Annual Review of Anthropology, 6, 349-378.

CUCU, A.-S. (2019). Planning Labour. Time and the Foundations of Industrial Socialism in Romania. In the series International Studies in Social History, Volume 32. New York, Oxford: Berghan Books.

HANN, C.M. (ed.) (1992). Socialism: Ideals, Ideologies, and Local Practice. London, New York: Routledge.

HANN, C.M. (ed.) (2002). Postsocialism: Ideals, Ideologies, and Practices in Eurasia. London, New York: Routledge.

ISER, W. (1978). The Act of Reading: A Theory of Aesthetic Response. Baltimore: Johns Hopkins University Press.

KIDECKEL, D. (1993). The Solitude of Collectivism: Romanian Villagers to the Revolution and Beyond. Ithaca, New York: Cornell University Press.

KLIGMAN, G. (1981). Căluș: Symbolic Transformation in Romanian Ritual. Chicago: University of Chicago Press.

KLIGMAN, G. (1988). The Wedding of the Dead: Ritual, Poetics, and Popular Culture in Transylvania. Berkeley: University of California Press.

KLIGMAN, G. (1998). The Politics of Duplicity. Controlling Reproduction in Ceauşescu's Romania. Berkeley: University of California Press.

KLIGMAN, G. (2017). Speech Given on the $25^{\text {th }}$ of May 2017 on the Occasion of Being Awarded the Doctor Honoris Causa Title of the Babeș-Bolyai University Cluj-Napoca. Studia UBB, Sociologia, 62(1), 19-28.

KLIGMAN, G. \& VERDERY, K. (2011). Peasants under Siege: The Collectivization of Romanian Agriculture, 1949-1962. Princeton: Princeton University Pres.

MARCUS, G.E. (ed.) (1992). Rereading Cultural Anthropology. Durham, NC, London: Duke University Press.

POENARU, F. (2017). The Knowledge of the Securitate Secret Agents as Anthropologists. Studia UBB, Sociologia, 62(1), 105-125.

RICOEUR, P. (1976). Interpretation Theory. Discourse and the Surplus of Meaning, Forth Worth. Texas: Texas Christian University Press.

VERDERY, K. (1983). Transylvanian Villagers. Three Centuries of Political, Economic, and Ethnic Change. Berkeley, Los Angeles, London: University of California Press.

VERDERY, K. (1991). National Ideology under Socialism: Identity and Cultural Politics in Ceaușescu's Romania. Berkeley: University of California Press.

VERDERY, K. (1996). What Was Socialism and What Comes Next? Princeton: Princeton University Press.

VERDERY, K. (2004). The Vanishing Hectare: Property and Value in Postsocialist Transylvania. Ithaca, London: Cornell University Press.

VERDERY, K. (2005). Chiaburii vechi și noi. Închiaburirea și deschiaburirea țăranilor din Aurel Vlaicu [Old and New Kulaks. Kulakisation and Dekulakisation of the Peasants in Aurel Vlaicu]. In D. Dobrincu \& C. lordachi (eds.), Puterea si țărănimea. Procesul de colectivizare a agriculturii în România, 1949-1962 [Power and the Peasants: The Process of Agricultural Collectivization in Romania, 1949-1962] (pp. 349-368). lași: Polirom.

VERDERY, K. (2014). Secrets and Truths (Natalie Zemon Davies Annual Lecture Series). Budapest: CEU Press.

VERDERY, K. (2018). My Life as a Spy. Investigations in a Secret Police File. Durham Carolina: Duke University Press. 